\title{
Incremental Impact of Venture Capital Financing*
}

\author{
Yan Alperovych \\ University of Liège - HEC Management School, \\ Liège 4000, Belgium \\ Tel: +32 (4) 2327430 \\ Email: y.alperovych@ulg.ac.be

\section{Georges Hübner} \\ University of Liège - HEC Management School, \\ Maastricht University, and Gambit Financial Solutions, \\ Liège 4000, Belgium \\ Tel: +32 (4) 2327428 \\ E-mail: g.hubner@ulg.ac.be
}

May 8, 2011

${ }^{*}$ This research is supported by the Belgian Fonds de la Recherche Fondamentale Collective (FRFC). We are grateful to Sophie Manigart, Mike Wright, and Bernard Surlemont for their useful comments and remarks on earlier versions of this paper. Georges Hübner thanks Deloitte Luxembourg for financial support. 


\begin{abstract}
Using a unique database of 990 VC-backed Belgian firms and a complete population of SMEs in Belgium, we investigate the differences in the return generating process in the venture capital-baked firms and their peers that operate without venture capital financing. Focusing on regular financial returns, we analyze the extent to which the presence of a venture capital investor affects the sensitivity of VC-backed firm's returns to the changes in capital structure, in operating cycle, and in the industry dynamics. The differences may occur from the self-/selection of better companies into venture capital portfolios, from venture capitalists' value-adding activities, and/or from both. We examine them in the context of complex simulation procedure with allows separating selection from value-adding when other traditional approaches are difficult to implement. Our results indicate that venture capital-backed firms are able to extract more rent from the changing industry conditions, and from the optimizations in capital structure and financing choices. The presence of the venture capitalists in the equity of the firm seem to have only a marginal effect on operating cycle efficiency. Overall the results are suggestive of the value-adding being the main driver for the VC-backed firm performance.
\end{abstract}

Keywords: Venture Capital; Performance; Simulation; Value-adding; Selection.

JEL classification: L22, L25, M13, G30 


\section{$1 \quad 1$ Introduction}

2 Venture capital and private equity (VC/PE) performance is often justified by two non-

exclusive features associated with this type of financing: selection and value-adding (Macmillan et al., 1987; Gorman and Sahlman, 1989; Sahlman, 1990; Sapienza, 1992; Brander et al., 2002; Baum and Silverman, 2004). Selection means that venture capitalists (VCs), especially more experienced and reputable ones, can invest into better quality targets with higher growth prospects (Sørensen, 2007). ${ }^{1}$ Value-adding relates to the active involvement of VCs in the ventures they fund (Sapienza et al., 1994; de Clercq and Manigart, 2007). Previous studies assert that VCs closely monitor, control, and manage their investments (Gompers, 1995; Davila and Foster, 2003; Kaplan and Schoar, 2005). To protect themselves from the management moral hazard issues, they write highly sophisticated contracts and design efficient covenants (Gompers and Lerner, 1996; Hellmann, 1998; Kaplan and Strömberg, 2004). To enhance operations of their targets, VCs make use of their large networks of potential clients and customers (Hochberg et al., 2007). Finally, they are able to assist their targets in strategic and (if needed) operational management, senior personnel recruitment, and additional financing arrangements (Gorman and Sahlman, 1989; Macmillan et al., 1989; Sapienza, 1992; Sapienza et al., 1994, 1996; Hellmann and Puri, 2002; Cumming et al., 2005; Dimov and Shepherd, 2005; de Clercq and Manigart, 2007).

Clearly, both selection and value-adding interact, which makes it difficult to separate the relative importance of each of these factors. This problem is particularly relevant for the comparison between the performance of venture capital-backed (VC-backed) firms with their non-VC-backed peers. Essentially, selection of better targets by a VC implies that her presence becomes endogenous to performance. The endogeneity occurs because

\footnotetext{
${ }^{1}$ Scholars also documented that prospective entrepreneurial firms may self-select themselves into a better VCs (Hsu, 2004).
} 
firms, which end up with venture capital financing, are inherently better along a number of unobserved characteristics than firms, which operate without venture capital support (Sørensen, 2007). Accounting for this, previous studies investigated the impact of venture capital on the innovation (Kortum and Lerner, 2000), on the probability of IPO (Sørensen, 2007), on the financial returns at a fund level (Kaplan and Schoar, 2005), and on the round-to-round/pre-IPO returns at the individual investment level (Cochrane, 2005; Hand, 2007).

This paper analyzes the impact of the VC's presence on the determinants of regular financial performance at the portfolio firm level. The extant literature on the determinants of financial performance of VC-backed firms isolate three relevant elements: capital structure, operating cycle, and industry dynamics (Tyebjee and Bruno, 1984; Gorman and Sahlman, 1989; Hellmann and Puri, 2000; Baeyens and Manigart, 2003; Bottazzi et al., 2008b). Our central assumption is that the interaction between selection and value-adding explicitly magnifies the effects of these elements. The main challenge, however, is the separation of selection from value-adding. To solve this issue, previous literature extensively used instrumental variable approach (like in Kortum and Lerner (2000) and Kaplan and Schoar (2005)) or Heckman's² sample selection models (like in Sørensen (2007) and Cochrane (2005)). These methods, however, require either exogenous and relevant instruments or the information on investor characteristics. Unfortunately, the nature of our data do not allow the use of these approaches. Instead, we are able to match VC-backed firms with the whole population of small and medium sized firms that operate without VC financing. Consequently, we develop a framework that separates selection from value-adding and quantifies the magnitude of the impact of VC's presence on the return determinants. Our main research question is therefore formulated as follows: how does selection and value-

\footnotetext{
${ }^{2}$ See Heckman (1976) and Heckman (1979).
} 
adding by a $\mathrm{VC}$ impact on the return generating process of underlying portfolio firms? Specifically, we investigate the extent to which the presence of a venture capital investor affects the sensitivity of VC-backed firm's returns to the changes in capital structure, in operating cycle, and in the industry dynamics.

The analysis exploits two raw datasets. The first set is a unique hand-collected sample of Belgian VC-backed companies, which received financing during 1998-2007. These data come from various secondary sources, like press-releases, funds' annual reports and web sites, and news databases. The second set is a complete population of Belgian firms over the same period. The disclosure of the standardized financial statements is mandatory for all firms operating in Belgium. Thus, the data are deemed to be reliable and homogeneous. Using the population we match VC-backed firms with their comparable peers and randomly permutate both sets. ${ }^{3}$ We then run our models on the original and permutated samples and store results. This procedure is repeated in a simulation setting, which ultimately allows us to trace the empirical distributions of the return determinants' loadings.

Consistent with the evidence on the VC's value-adding, our findings indicate that the presence of VCs among the shareholders of an underlying portfolio firm increases the sensitivity of its regular financial returns to changes in its determinants. Moreover, these shifts are likely to be independent of selection. Specifically, returns of the VC-backed firms react much faster to the changes in capital structure, and to the changes in industry dynamics, compared to their non-VC-backed peers. The changes in the operating cycle seem to have a very close effect on the future performance of the VC-backed firms and their peers. Finally, returns of VC-backed firms seem to be nonlinear in their determinants, and these nonlinearities are exaggerated by the presence of venture capital investor. These findings suggest that VCs add the most of the value in the capital structure management and managerial

\footnotetext{
${ }^{3}$ The permutated samples are assumed to represent the general economic landscape in which portfolio companies operate.
} 
advise.

The remainder of the paper is organized as follows. Section 2 discusses the theoretical reasoning of this paper. Section 3 presents the data and research design. Section 4 outlines the results. Finally, Section 5 concludes.

\section{VCs' selection, value-adding, and performance}

Entrepreneurial firms often face difficulties in obtaining external financing (Gompers and Lerner, 2001). They are typically characterized by high levels of information asymmetry, operate in highly uncertain environments, and have very few tangible assets. Because of this, traditional fund providers, such as banks, may be reluctant to provide financing to these businesses (Wright and Robbie, 1998; Gompers and Lerner, 2004). Frequently, though, such firms have high growth prospects and can potentially yield handsome returns to investors. As such, venture capitalists invest in these firms to benefit from this perceived growth and return potential.

VCs excel in "picking winners" and reducing information gaps around entrepreneurial firms (Baum and Silverman, 2004). Their thorough due diligence process, sophisticated contracting, and selection criteria allow entrepreneurs to receive the financing, which they could not obtain from other sources (Macmillan et al., 1985; Gorman and Sahlman, 1989; Brander et al., 2002; Kaplan and Strömberg, 2003; Baum and Silverman, 2004; Kaplan and Strömberg, 2004). It has been observed that VC-backed firms show superior performance with respect to their non-VC-backed peers (Cochrane, 2005; Kaplan and Schoar, 2005; Korteweg and Sørensen, 2010). However, this may be an artifact of venture capital investors' selection process or of a self-selection of potentially best targets into very reputable and experienced venture capital investors (Hsu, 2004; Sørensen, 2007). If this conjecture holds, it is then straightforward that venture capital financing would have the same effect on any 
firm, which is comparable to the eventual VC-backed one prior the investment.

Yet, a substantial literature asserts that venture capital investors are actively involved in the ventures they fund. It is this involvement, which significantly enhances the value of the venture after the initial investment (Wright and Robbie, 1998; Gompers and Lerner, 2001, 2004; Bottazzi et al., 2008b). More specifically, investors' involvement may impact on several functional mechanisms in portfolio firms.

First, it may affect the ways products are produced or sold. VCs actively participate in the board of directors of their portfolio firms (Tyebjee and Bruno, 1984; Gorman and Sahlman, 1989). They closely monitor and control their targets, which provides additional information about the development of their investments, asserts the managerial discipline, incentives realignment. Obviously, this protects investors from managerial moral hazard problems and significantly reduces wasteful expenditures (Jensen and Meckling, 1976; Gompers, 1995; Gompers and Lerner, 2001; Cumming and Johan, 2008). Their participation also implies provision of advisory services to the entrepreneurs (Cumming and Johan, 2008), including managerial, strategic, and marketing advices (Sapienza, 1992; Sapienza et al., 1994). Besides operational and strategic management, VCs may help their portfolio companies with finding appropriate professional senior executives, especially when entrepreneurs themselves lack skills in key areas of management (Hellmann and Puri, 2002; Bottazzi et al., 2008b). Last but not least, venture's development can be facilitated by the access to the VCs' developed networks of business advisors, lawyers, suppliers, potential clients, customers, and partners (Hochberg et al., 2007; Cumming and Johan, 2008). At the investee's operational level this may translate into more adequate cost structure and increased revenues from operations.

Second, it may influence the underlying portfolio firm's capital structure and financing choices at and after the initial capital injection. Prior to the investment, high uncertainty, 
potential for agency problems, and little tangibility of assets, which may serve as collateral, considerably limit the range of possible financing sources (Gompers and Lerner, 2001; de Bettignies and Brander, 2007; de Bettignies, 2008). In this sense, venture capital financing serves as a viable alternative to the bank capital. Depending on the instrument used by the venture capitalist to channel funds into the venture ${ }^{4}$, post-investment capital structure of the underlying portfolio firm may experience some changes (Cumming, 2005; Hellmann, 2006). In addition, the arrival of venture capitalist also sends a strong positive signal about the quality of the venture and its future prospects to external fund providers (Megginson and Weiss, 1991; Baeyens and Manigart, 2003; Cornelli and Yosha, 2003; Gompers and Lerner, 2004; López-Gracia and Sogorb-Mira, 2009). Venture capitalist's involvement further facilitates negotiations and contracting for additional financing with third parties (Gorman and Sahlman, 1989; Baeyens and Manigart, 2003). Finally, contracts between VCs and entrepreneurs coerce additional discipline in the nature, sources, and uses of subsequent funds raised from third parties (Kaplan and Strömberg, 2003, 2004). It is therefore plausible to assume that financing decisions by entrepreneurial firms could be more optimal and tailored to the needs of the underlying firm in comparison to the firms without VC-backing.

Third, venture capitalists typically invest in innovative ventures in new and highlydynamic industries (Kortum and Lerner, 2000; Gompers and Lerner, 2001). To provide proper guidance to such firms, venture capital managers need significant previous experience both as venture investor, as industry player, and sometimes as entrepreneur (Bottazzi et al., 2008b). Not surprisingly, many top VC managers have previous consulting and entrepreneurial experience (Knockaert et al., 2006). This experience may help VCs better

\footnotetext{
${ }^{4}$ The literature suggests that traditional instruments are convertible securities, like convertible preferred equity (Sahlman, 1990; Cornelli and Yosha, 2003; Kaplan and Strömberg, 2003; Hellmann, 2006). Some scholars argue, however, that this conjecture is particular to the US venture capital industry and need not hold in other countries (see for example Cumming (2005)).
} 
understand and develop appropriate (re)actions to the changes in the underlying market/industry conditions. Scholars documented that human capital characteristics of VCs help reducing the failure rate of the portfolio firms (Dimov and Shepherd, 2005). It has also been shown that VC's involvement affects underlying portfolio firm's strategic choices in terms of product market strategies (Hellmann and Puri, 2000). It is therefore straightforward to assume that VC-backed firms will further benefit from changes in respective industry conditions in comparison to their non-VC-backed peers.

The foregoing mechanisms are directly related to the regular financial performance of the portfolio firms. The selection argument, however, implies that VC-backed firms should be indistinguishable from their non-VC-backed peers as long as their comparability is asserted. This means that changes in these factors will affect the performance of both type of entrepreneurial firms in the same way, which leads to the following hypotheses:

H1a: Financial performance of VC-backed firms and their non-VC-backed peers will be affected in the same way by the changes in the operating cycle in these firms.

H2a: Financial performance of VC-backed firms and their non-VC-backed peers will be affected in the same way by the changes in the capital structure in these firms.

H3a: Financial performance of VC-backed firms and their non-VC-backed peers will be affected in the same way by the changes in the external environment around these firms.

The value-adding arguments suggest that operations of VC-backed firms are more efficient ${ }^{5}$, and that financing and strategic decisions are more appropriate to the dynamic environment around these firms. Under such structure, we may expect VC-backed firm's performance to react faster to the changes in these factors in comparison to the non-VCbacked peers. This discussion leads to the following set of alternative hypotheses:

H1b: Financial performance of VC-backed firms will be more sensitive to the changes in the operating cycle compared to non-VC-backed firms.

\footnotetext{
${ }^{5}$ Even if the efficiency is not an objective, we may expect that VC's involvement still benefit the operating process in terms of cost-reductions and value enhancements.
} 
H2b: Financial performance of VC-backed firms will be more sensitive to the changes in the capital structure compared to non-VC-backed firms.

H3b: Financial performance of VC-backed firms will be more sensitive to the changes in the corresponding external environment compared to the non-VC-backed firms.

\section{Method and data}

The test of the foregoing hypotheses is directly related to the selection and value-adding arguments proposed in the literature. Separating the two is a very challenging task. Because of the selection, venture capital financing becomes endogenous to performance, which inflates the values of parameters of performance factors. Include value-adding activities into the picture, and the effect of the performance factors could be even more exaggerated. The classical solution to the endogeneity problem is the instrumental variable (IV) approach. However, Sørensen (2007) argues that IV requires appropriate (exogenous and relevant) instruments, which are not readily available for analysis in the venture capital context. Instead, he suggests to estimate a structural model, similar to the two-stage Heckman's selection models (Heckman, 1976, 1979). This approach makes use of a selection equation, which, in turn, requires observable information on the investor characteristics. In our case, the latter are not available, thus we need an alternative solution.

The procedure devised for testing the proposed conjectures is based on the simulation method. We use two types of datasets, which we call main sample (MS) and peer groups (PG). The construction of each of the samples is described below.

\subsection{Sample construction}

The empirical setting of this paper is the Belgian venture capital industry during the period 1998-2007. We use a list of 1,050 Belgian companies that received venture capital financ- 
ing (only the first injection dates are available) during the mentioned period. ${ }^{6}$ This list comes from various secondary sources, which include Factiva search engine, news archives, venture capital funds' annual reports, various press releases, newsletters, and announcements. In order to ensure the validity of the observation units, we manually cross-checked, whenever possible, each entry between the mentioned sources and the VentureEconomics and/or ZEPHYR databases. ${ }^{7}$ Each entry of the raw data contain information on the date of financing round and the target company's national identification number. Using this number we are able to extract firm-specific data from the BELFIRST database. The latter include complete annual financial reports (over the specified period) as well as the industrial sector codes (NACE-BEL 200821 class), and the firms' creation dates. ${ }^{8}$ Excluding unusable observations, VC-backed investments in the financial and real estate sectors, management buyout deals, and listed companies, we obtain a main sample (MS) of 990 firms that had received venture capital financing. Finally, we use the data from National Institute of Statistics on the total assets in each industry present in the sample (NACE-BEL 21 class) during the specified period.

Peer groups $(\mathrm{PG})$ are constructed in several steps, following the matching procedure suggested by Megginson and Weiss (1991), Lerner (1999), and Manigart et al. (2002). First, for each VC-backed firm in the sample we record the values of total assets and total revenues in the year immediately prior to the venture capital injection. ${ }^{9}$ Next, using NACEBEL 200821 class codes (3 digits), each VC-backed firm in the MS is matched with its respective industry. Basing on the amounts of total assets and total revenues, noted earlier,

\footnotetext{
${ }^{6}$ It is worth noting that this list is all we have as an initial input. Unfortunately, we do not possess any information regarding the investor or the deal, e.g., the valuation, the number of subsequent financing rounds, the investor type, the syndication, etc.

${ }^{7}$ The coverage of Belgian venture capital deals in these databases is far from complete.

${ }^{8}$ All companies in Belgium, regardless their listing status or size, are obliged to file complete financial statements with the National Bank of Belgium. They are next compiled into the commercially available BELFIRST electronic database.

${ }^{9}$ For start-ups, we took the corresponding values in the injection year.
} 
we identify to which empirical decile of the corresponding industry each VC-backed firm belongs. Finally, we create a PG, set, which consists of all firms from the same industry decile as the underlying portfolio firm, plus all firms from the following and preceding deciles. The reason to take three deciles is that, sometimes, industrial sectors are too small; the number of firms in the decile may bee too limited to qualify for a usable peer group. ${ }^{10}$ Thus, for each portfolio firm in the MS there is a corresponding PG, which includes all firms from the same industrial sector with a comparable levels of total assets and total revenues prior/in the year this portfolio firm had received VC financing. These PGs are assumed to represent the sub-populations of potential targets that might have received the venture capital backing. The size of peer groups vary from 12 to 6869 firms, depending on the industry sector of the corresponding VC-backed firm.

\subsection{Permutation procedure design}

The procedure is designed to randomly create a control sample (CS) from the combination of the MS and the PGs. For this, we first generate a random integer $R_{1}{ }^{11}$, which indicates the number of firms of the MS to be replaced by the firms coming from the PGs. Next, a pair of random integers $\left(R_{2_{i}}\right.$ and $\left.R_{3_{i}}, i=1, \ldots, R_{1}\right)$ are simultaneously created $R_{1}$ times. ${ }^{12}$ Each $R_{2_{i}}$ serves as an identifier of the VC-backed firm from MS to be replaced by one of the firms from its corresponding PG. To ensure that the same MS-firm is not replaced twice, $R_{2_{i}}$ are nonrecurrent for all $i$. Each $R_{3_{i}}$ identifies a firm from the PG, corresponding to the current VC-backed firm with the identifier $R_{2_{i}}$. Note that many of the VC-backed firms in the MS may come from the same industrial sectors. This does not necessarily imply that their PGs are identical, although, it is technically possible. There may be cases when PGs

\footnotetext{
${ }^{10}$ If a portfolio firm belongs to the first or the last decile of its industry, only following or preceding deciles respectively are taken.

${ }^{11}$ All random integers here are generated assuming the uniform distributions.

${ }^{12}$ Note that $R_{3_{i}}$ depends on the size of the PG corresponding to $R_{2_{i}}$.
} 
are overlapping as well. Moreover, $R_{3_{i}}$ itself can be recurrent. In all these cases, a same firm from the PGs may be selected multiple times to enter the CS. In such particular cases, we control for the national identification number of that firm and, if necessary, regenerate $R_{3_{i}}$. This kind of randomized permutation ultimately provides the CS. It consists of a mix of VC-backed firms and their comparable peers that could have been financed by VC, but operated without it.

\subsection{Variables and simulation structure}

Financial performance of the VC-backed firms and their peers is measured annually as a ratio of free cash flow over shareholders equity. To avoid the causality problems, all independent variables are one year lagged.

To test if there is an effect of the VC's presence on the operating cycle of an underlying portfolio firm, we use an annual ratio of value added over total assets. This measure takes into consideration the efficiency in the cost structure of the portfolio firm and its sales capacity. It has been shown that financial performance is directly affected by the efficiency (Bottazzi et al., 2008a). In the context of this analysis, we expect a positive relationship between this factor and financial performance.

To test if there is an effect of the VC's presence on the subsequent capital structure and financing choices of an underlying portfolio firm, we use an annual equity ratio, defined as shareholders equity over total assets. This measure takes into consideration the capital structure and size effects (Ooghe and Wymeersch, 2006). According to the capital structure and financing choice theories (Myers and Majluf, 1984; López-Gracia and Sogorb-Mira, 2009; Vanacker and Manigart, 2010) financial performance is expected to be negatively affected by the increases in equity.

To test if there is an effect of the VC's presence on the sensitivity of portfolio firm's 
return to the changes in external environment, we compute the industrial growth rates (annual log change of the total industrial assets). We assume that young and developing industries would have more volatile growth rates (Klepper and Graddy, 1990; Klepper, 1997; Klepper and Simons, 2005). Returns are expected to be positively affected by the changes in this variable. The sectors are aggregated using the first three digits of the NACE-BEL code. This ensures the consistency with MS-PG matching procedure, which is also based on the three digit correspondence.

Several additional controls are also included. According to Ooghe et al. (2006) and Bottazzi et al. (2008a), there are four dimensions crucial to the financial situation of the company: profitability, liquidity, financial structure, and added value. We use four supplementary measures of liquidity, one measure of financial structure, and one measure of profitability. Also, we control our model for the dividends payouts. Three explicit control variables are used to account for the firm's age (log of the age, measured in years since creation, $A G E$ ), for the number of employees (log of the number of employees in each year, $E M P L)$, and for the year in which the venture capital injection takes place (dummy variable that takes the value of one from the moment of the arrival of $\mathrm{VC}$ onwards, INJYEARDUM $).{ }^{13}$ Following tables report the definitions of the variables used in the analysis, their basic statistics and the correlation matrix.

\footnotetext{
${ }^{13}$ Some companies in the sample show zero values of $A G E$ and $E M P L$. AGE is 0 if a company is venture backed from inception. We force NA initial value for the $A G E$ in such cases. $E M P L$ may take the value of 0 when company does not employ staff in the legal sense, e.g., contract workers with the status "independent". We add 1 to the EMPL variable to force the existence of logs.

${ }^{14}$ We checked for the partial correlations with lags (Ljung-Box Q-stat) as well as for the presence of the
} 
variables, we first set a basic autoregressive empirical model:

$$
C F_{-} E_{i, t}=C_{i}+\delta C F_{-} E_{i, t-1}+\epsilon_{i, t}
$$

where subscripts $t$ and $i$ denote the time and company, respectively. Second, the residuals of the Equation (1) are used as the response variable to control for the dependency between the regressors $(X)$ we use in our principal model:

$$
\epsilon_{i, t}=\gamma_{i}+\gamma X_{i, t-1}+u_{i, t}
$$

Finally, we reconfigure the principal model using Equations (1) and (2) such that

$$
C F_{-} E_{i, t+1}=\beta_{i}+\beta X_{i, t}+\beta^{*} u_{i, t}+v_{i, t+1}
$$

Equation (3) posits that the future value of the cash flow over equity of a company $i$ depends on the current values of regressors. ${ }^{15}$

The simulation is structured in the following way. First we estimate the parameters for the MS only. Once a CS is finalized, we estimate model on it and store the parameters. After that, the current CS is deleted, and we repeat the permutation procedure to recreate a new CS and reestimate the model. This resampling is reiterated 10000 times, which yields the empirical distributions of the sensitivities of factors discussed in the previous section. We believe that such randomized permutation procedure allows the separation of the selection effect from the value-adding effect. If we assume that VCs' presence is of no consequence, i.e. only selection matters, then there should be no significant differences between the unit roots (Im, Pesaran and Shin W-stat, ADF Fisher CHI-square, PP Fisher Chi-square) in all series. Data and tests are available upon request.

${ }^{15}$ The first loading $\left(\beta_{i}\right)$ represents the cross-section fixed effect constant, followed by the common factor betas, which are assumed to be constant over time and cross-sections. The term $u_{i, t}$ should be considered as an independent variable in Equation (3), since its value is determined earlier in Equations (1) and (2). 
sensitivities estimated on the MS-only sample and the the average of sensitivities from the simulations. Alternatively, if VCs do bring changes and additional value to their portfolio firms, we should observe significant changes in the sensitivities.

\section{Results}

Two distinct specification approaches are used to test the proposed hypotheses. To begin, we benefit from the availability of the annual financial data on each portfolio firm to estimate the standard panel regressions in each iteration. The results of this approach are discussed in the first part of this section. We continue our analysis with the closer examination of the left-hand side of specification equation. The rationale and results of this analysis are presented in the second part of this section.

\subsection{Panel approach}

Panel regressions are estimated in three steps following the specifications of Eq. (1) - (3) with robust standard errors and cross-section fixed effects. Table 3 reports the results. First, consider the MS estimates. The sensitivities of equity ratio $\left(E \_T A\right)$, value added over assets $\left(V A \_T A\right)$, and industrial growth rate $(\Delta(L O G I N D))$ are statistically significant and consistent with the sign predictions. A unit increase in the equity ratio, which is equivalent to raising the relative amounts of equity in the firm, reduces future financial performance by about 0.281 units. Second, the sensitivity of the operating cycle efficiency has a positive, as expected, and significant effect on the future performance. A unit increase of the value added over assets yields about $3.6 \%$ increase in the future free cash flow over equity of the underlying portfolio firm. Finally, positive and statistically significant effect is verified for the industrial growth rate. In this case, a unit growth in the industrial assets, the proxy for the dynamics of external environment, increases the future financial performance 
by about one thirds.

TABLE 3 HERE

The right-hand side of the table reports the results of the MC simulation. First, note that the simulated distributions ${ }^{16}$ of the main variables are non-normal. Conventional Jarque-Bera tests (not reported in the table) reject the null hypothesis of normality in all cases. All distributions appear to be non-centered, skewed and leptokurtic (see Figure 1). Next, consider the main point of the simulations, namely, the substantial differences between the averages of the simulated distributions and the MS estimates. Figure 1 provides a clear visual representation. Table 4 reports the formal tests of the differences between the simulated means and the MS estimates.

\section{FIGURE $1 \&$ TABLE 4 HERE}

The MS estimate of the operating cycle $\left(V A_{-} T A\right)$ variable is more pronounced $(0.036$ vs. 0.029) and statistically different from the simulated mean, leading to the support of H1b (and the rejection of H1a). The size of the implied difference indicates that the VC's presence in the equity of the entrepreneurial firm translates in about $24.14 \%$ improvements in the efficiency of the operating cycle. This is quite remarkable, especially considering that our matching procedure aims at ensuring that non-VC-backed firms are as comparable to the VC-backed ones as possible. Although the efficiency of the operating cycle might not be the objective in early-stage ventures, the VC value-adding efforts in monitoring, control, and managerial advice may still result in optimizations in the operating cycle.

\footnotetext{
${ }^{16}$ For convenience, we use terms "simulated mean", "simulated average", "mean of the simulated distribution" and "average of the simulated distribution" interchangeably.
} 
The MS estimate of the capital structure $\left(E A \_T A\right)$ variable shows some unexpected results. First, it appears to be greater than the simulated mean (-0.281 vs. -0.300). Second, the implied difference of about $6.3 \%$ is significant (see Table 4). This structure suggests that future increases in the financial performance due to reductions in equity are more pronounced when VC is not present in the firm. In other words, non-VC-backed firms benefit more from the increases in debt levels compared to their VC-backed peers. This suggests the rejection of $\mathrm{H} 2 \mathrm{a}$. Concerning the $\mathrm{H} 2 \mathrm{~b}$, however, some clarification might be necessary. Specifically, VC-backed firms may be more levered than their non-VC-backed peers. In a study of the dynamic financing strategies of the Belgian VC-backed firms, Baeyens and Manigart (2003) indicate that VC-backed firms have significantly greater debt levels in comparison to their non-VC-backed peers. According to the traditional capital structure theory, the debt has the marginally decreasing effect (Myers and Majluf, 1984; Frank and Goyal, 2007). Consequently, a unit increase of debt in the non-VC-backed firm may result in a more substantial increases in the future financial performance, compared to the VC-backed firms. This seems to be more consistent with the simulation results. Moreover, this suggests some nonlinear effects of the capital structure variable, which are tested in the following section. We will come back to the H2b after these analyses.

Finally, the MS estimate of the industrial growth rate $(\Delta(L O G I N D))$ variable is, as expected, much greater (0.322 vs. 0.171$)$ and statistically significant from the simulated mean, supporting the H3b. The implied difference is as high as $88.33 \%$, suggesting that VCbacked firms react much faster to the changes in the underlying industry conditions. If we regard the implied difference as the effect of VC's presence, hence, of the value-adding and monitoring activities, this suggests the substantial benefits of the venture capital financing.

On balance the results seem to be in line with our discussion on the incremental impact of $\mathrm{VC}$ financing due to value-adding. An alternative explanation, namely, the selection 
hypothesis suggests that VCs just select better companies (Baum and Silverman, 2004; Sørensen, 2007). If that is the case, then the seemingly superior performance of the VCbacked firms should be replicated by their comparable non-VC-backed peers. Therefore, the sensitivities of returns to the changes of the corresponding determinants should be indistinguishable for both VC-backed firms and their peers. Following our results, we posit that selection is highly unlikely to be a main factor for the VC performance.

\subsection{Quantile approach}

Our previous discussion of the $\mathrm{H} 2 \mathrm{~b}$ pointed out on the possible nonlinear relationship between the factors affecting financial performance and the performance itself. Why should we expect such a relationship? According to a recent and growing stream of literature, the growth of small firms is nonlinear in its determinants (Landajo et al., 2008). For example, Jovanovic (1982) suggests firm's growth diminishes with its age, while other studies show that a firm's growth diminishes with size (Serrasqueiro et al., 2009). Bottazzi et al. (2008a) argue that growth influences financial performance, and we have already discussed that VC-backed firms are characterized by high growth opportunities. Therefore, we might detect a nonlinearity in the firm-specific factors of financial performance as well.

In a more general way, VC-backed firm may be viewed as a portfolio of growth options (Trigeorgis, 1999). Some of these options are straightforward. Others are activated only upon realization some prerequisites - options themselves. For example, impressive returns on investment in a biotech firm could be triggered if this firm successfully passes all necessary clinical trials. In addition to the main objective of research, the R\&D process may yield some spillover results as well. In this context, the role of VCs is twofold. First they are able to detect these options (selection) and stipulate/accelerate their execution (valueadding). Thus, because of these option-like characteristics we may observe a nonlinearity 


\footnotetext{
${ }^{17}$ For example a median regression is a particular case of quantile regression when the dependent variable is conditional median.

${ }^{18}$ For more details, see preceding chapter and Koenker and Basset (1978) \& Koenker and Hallock (2001).

${ }^{19}$ The estimates of the simulated distributions for control variables are available upon request.
} 
lated parameter distributions vary from $0.004(\tau=0.1)$ to about $-0.404(\tau=0.9)$. The distributions themselves are skewed and leptokurtic. In line with our previous discussion of $\mathrm{H} 2 \mathrm{~b}$, the simulated means exceed MS estimates in all cases. The penalizing effect of under-leverage increases over the quantile of performance, i.e. the difference between the MS estimate and simulated mean is growing. The effect of the capital structure on the future performance can be considered as linear in the corresponding quantiles. For the example, the results for the last quantile $(\tau=0.9)$ suggest that future returns of the most performing VC-backed firms are much more sensitive to the changes in the firm's capital structure than the returns of comparable firms, again in line with H2b. Specifically, for the VC-backed firm from the top quantile of the financial performance distribution, a unit increase of equity reduces future returns by -0.498 units. We observe the same patterns in the simulated means, however the magnitude is not as pronounced as in the VC-backed firm case.

Panel B and Figure 3 show the results for the value added over assets variable. MS estimates and simulated means of the quantile process follow a somewhat growing pattern. For both MS estimates and the simulated means, the effect of the operating cycle efficiency is negative in the lowest quantiles, and positive in the highest quantiles of the distribution. Simulated means switch sign around the median of the distribution, whereas MS estimates do so after the fourth quantile $(\tau=0.4)$. The differences between the simulated means and MS estimates are partially in line with the H1b. This is because the positive impact of the VC's presence is strongly observable in the middle of the distribution, in the fifthto-seventh quantiles. To give an example, MS estimations show that the coefficient of the value added over assets variable is negative $(-0.027)$ and lower than the simulated mean $(-0.018)$ for the least performing firms (bottom quantile, $\tau=0.1$ ). Simulated means show that in the top quantiles of the distribution a unit increase of the value added over assets 
ratio yields about $2.4 \%$ increase in the future financial performance. In the case of VCbacked firm, this increase is about 2.0\%. The MS estimate however, is always greater than the simulated mean between the third and seventh quantile. The difference between the simulated means and MS estimates seem to converge towards the top quantile of the performance distribution. On balance, this structure suggests several considerations. First, because of the very narrow difference between the simulated means and MS estimates in the top quantile, VC's presence in the equity of the underlying portfolio firm does not seem to affect operating cycle efficiency much. This may happen because VC-backed firms and their peers are very close in terms of optimization of their operating cycles. Second, VC's presence does make portfolio firm react faster to the changes in operating cycle, if the firm is in the middle of the performance distribution. Third, the bottom quantiles suggest that VC's presence slightly reduces the sensitivity of financial performance to the changes in the operating cycle. The last two parts may be related to the findings on the VC's involvement. Specifically, the literature suggests that VCs spend more effort on the ventures, which are already performing well (Sapienza, 1992; Sapienza et al., 1994, 1996), forcing the greater negative effect of the VC's presence in the bottom quantiles. Finally, the negative values of the sensitivities in these quantiles are probably related to the fact that, at this cashburn stage of firm's development, reaching the optimum in the production efficiency is not beneficial. In any case, it appears that value-creation in the VC-backed firms is not rooted in the optimization of the operating cycle.

Panel $\mathrm{C}$ and Figure 4 report the results for the industry growth rate variable. It follows, that in the lowest quantiles $(\tau \in[0.1 ; 0.4])$ the average impact of the industry related variable is negative, and that it switches its sign in the following quantiles. Original MS estimates are negative and lower than the simulated means in the first quantile, but turn positive and greater then simulated means in all subsequent quantiles. VC-backed firms 
seem to react much faster to the changes in the industrial dynamics in comparison to the simulated means. The impact of the industrial growth rate on future performance of the most performing VC-backed firms $(\tau=0.9)$ is the highest in comparison to their non-VCbacked peers (0.552 vs. 0.360). This difference seems to be greater in the outer quantiles $(\tau \in[0.1 ; 0.3]$ and $\tau \in[0.7 ; 0.9])$, and moderate in the middle quantiles. This suggests that the magnification effect of the presence of the $\mathrm{VC}$ is more pronounced in the low performing and high performing firms. This structure is in line with H3b, and implies that VC-backed firms are able to extract considerable value from the dynamics of external environment.

On balance, we observe that VC presence in the company amplifies the portfolio firm's reaction to the changes in the capital structure and in the industry dynamics. To a lesser extent the same conclusion can be applied to the operating cycle efficiency variable.

\section{Concluding remarks}

This paper explores the incremental impact of the venture capital financing in the simulation setting. Specifically, we examine whether the regular financial returns of VC-backed firms are due to self-selection (Sørensen, 2007) or value-adding. We draw our assumptions following the insights of venture capital literature on the three determinants of financial performance: operating cycle efficiency, capital structure/financing choices, and dynamics of the industry. Consequently, we build our main assumption that the presence of the venture capitalist in the equity of the firm exaggerates the impact of these factors. Using the complex sample construction procedure, three-step regression method and two different estimation approaches, we are able to quantify the magnitude of these shifts. The central findings can be summarized as follows.

First, the traditional regression approach points out that venture capital-backed firms are able to extract more rent from the changing industry conditions, and to an extent from 
the operating cycle optimization. The sensitivity of the financial returns of VC-backed firms to the changes in these factors is always greater than it is in comparable firms. It seems that because of the generally higher leverage levels in the VC-backed firms, the sensitivity of the regular financial returns to the changes in capital structure seem to be lower in VC-backed firms, than in their comparable peers. However, this evidence is directly related to the nonlinear relationship between the financial return and its determinants. In this context, our second finding suggests that capital structure, or financing choices, and industry dynamics are the main sources of return generation in VC-backed firms. In both cases, such firms react faster and stronger to the changes in these factors in comparison to the sensitivities of their non-VC-backed peers. This is especially relevant to the most performing firms, as the sensitivity of their returns seem to be the highest. Underperforming firms still benefit from VC's presence, however, the effect decays with performance. Concerning the operating cycle efficiency, we find the weak evidence that returns of average performing VC-backed firms react slightly faster to the changes in operating cycle, whereas the difference is almost negligible in the most performing firms (both VC-backed and non-VC-backed ones).

One of the implications of this study is that we are able to measure and test the impact of the VC presence on the determinants of firm's regular performance at a company level. Moreover, our findings indirectly support the value-adding hypothesis of venture performance, consistent with the traditional literature (Wright and Robbie, 1998; Brander et al., 2002; Wood and Wright, 2009). The simulation procedure allows us to overcome to an extent the selection bias issues (Manigart et al., 2002; Bottazzi et al., 2008b), when the instrumental variable and/or structural models are difficult to implement. Finally, our results point out the possibility that value-adding by venture capital investor is mainly concentrated in the capital structure decisions and the decisions linked with strategic management advise. 
Some future developments in this direction are possible. For example, due to the nature of our data, we are unable to control directly for the VC's type, experience, reputation, and level of involvement. Consequently, it is impossible to test whether a particular investor, a more experienced, or reputable one, is associated with specific areas of firm performance. For example, captive venture capitalists related to banks and other financial institutions may put more emphasis on the financing choices and capital structure optimization in the portfolio firms. Alternatively, investors experienced in a particular industry may better affect the way portfolio firms integrate in their respective industries. This, in turn, could explain why, in some cases, the presence of $\mathrm{VC}$ is beneficial, and in others is only marginal. Our analysis assumed constant effects of the return determinants over time, hence the differences in sensitivities of VC-backed firms and their peers are set to be stable. It is however plausible to assume that comparable firms may show some convergence to the VC-backed firms in a longer time horizon. The analysis of this structure, however, would require much larger sample that we currently have. 
523

\section{References}

Alperovych, Y. and Hübner, G. (2011). Explaining returns on venture capital backed companies: evidence from Belgium. Research in International Business and Finance, 25(3):277-295.

Baeyens, K. and Manigart, S. (2003). Dynamic financing strategies: the role of venture capital. The Journal of Private Equity, 7(1):50-58.

Baum, J. A. and Silverman, B. S. (2004). Picking winners or building them? Alliance, intellectual, and human capital as selection criteria in venture financing and performance of biotechnology startups. Journal of Business Venturing, 19:411-436.

Bottazzi, G., Secchi, A., and Tamagni, F. (2008a). Productivity, profitability and financial performance. Industrial and Corporate Change, 17(4):711-751.

Bottazzi, L., da Rin, M., and Hellmann, T. (2008b). Who are the active investors? Evidence from venture capital. Journal of Financial Economics, 89:488-512.

Brander, J. A., Amit, R., and Antweiler, W. (2002). Venture-capital syndication: improved venture selection vs. the value-added hypothesis. Journal of Economics and Management Strategy, 11(3):423-452.

Cochrane, J. H. (2005). The risk and return of venture capital. Journal of Financial Economics, 75:3-52.

Cornelli, F. and Yosha, O. (2003). Stage financing and the role of convertible securities. Review of Economic Studies, 70:1-32.

Cumming, D., Fleming, G., and Suchard, J.-A. (2005). Venture capitalist value-added activities, fundraising and drawdowns. Journal of Banking and Finance, 29:295-331.

Cumming, D. and Johan, S. (2008). Information asymmetries, agency costs and venture capital exit outcomes. Venture Capital, 10(3):197-231.

Cumming, D. J. (2005). Capital structure in venture finance. Journal of Corporate Finance, 11:550-585.

Davila, A. and Foster, G. (2003). Staging venture capital: empirical evidence on the differential roles of early versus late rounds. Working paper.

de Bettignies, J.-E. (2008). Financing the entrepreneurial venture. Management Science, 54(1):151-166.

de Bettignies, J.-E. and Brander, J. A. (2007). Financing entrepreneurship: bank finance versus venture capital. Journal of Business Venturing, 22:808-832.

de Clercq, D. and Manigart, S. (2007). The venture capital post-investment phase: opening the black box of involvement, in "Handbook of research on venture capital", chapter 7, pages 193-218. Edward Elgar Publishing Inc.

Dimov, D. P. and Shepherd, D. A. (2005). Human capital theory and venture capital firms: exploring "home runs" and "strike outs". Journal of Business Venturing, 20:1-21.

Frank, M. Z. and Goyal, V. K. (2007). Trade-off and pecking order theories of debt. Working paper.

Gompers, P. (1995). Optimal investment, monitoring, and the staging of venture capital. Journal of Finance, 50:1461-1490. 
Gompers, P. and Lerner, J. (1996). The use of convenants: an empirical analysis of venture partnership agreements. Journal of Law and Economics, 39(2):463-498.

Gompers, P. and Lerner, J. (2001). The venture capital revolution. Journal of Economic Perspectives, 15(2):145-168.

Gompers, P. and Lerner, J. (2004). Venture capital cycle. The MIT Press, Cambridge, Massachusetts, London, England, 2 edition.

Gorman, M. and Sahlman, W. A. (1989). What do venture capitalists do? Journal of Business Venturing, $4(4): 231-248$.

Hand, J. R. (2007). Determinants of the round-to-round returns to pre-IPO venture capital investments in U.S. biotechnology companies. Journal of Business Venturing, 22:1-28.

Heckman, J. J. (1976). The Common Structure of Statistical Models of Truncation, Sample Selection and Limited Dependent Variables and a Simple Estimator for Such Models in "Annals of Economic and Social Measurement", volume 5, pages 120-137. NBER.

Heckman, J. J. (1979). Sample selection bias as a specification error. Econometrica, 47(1):153-161.

Hellmann, T. (1998). The allocation of control rights in venture capital contracts. RAND Journal of Economics, 29(1):57-76.

Hellmann, T. (2006). IPOs, acquisitions, and the use of convertible securities in venture capital. Journal of Financial Economics, 81:649-679.

Hellmann, T. and Puri, M. (2000). The interaction between product market and financing strategy: the role of venture capital. Review of Financial Studies, 13(4):959-984.

Hellmann, T. and Puri, M. (2002). Venture capital and the professionalization of start-up firms: empirical evidence. Journal of Finance, 57(1):169-197.

Hochberg, Y. V., Ljungqvist, A., and Lu, Y. (2007). Whom you know matters: venture capital networks and investment performance. Journal of Finance, 62(1):251-301.

Hsu, D. H. (2004). What do entrepreneurs pay for venture capital affiliation? Journal of Finance, $59(4): 1805-1844$.

Jensen, M. C. and Meckling, W. H. (1976). Theory of the firm: Managerial behavior, agency costs and ownership structure. Journal of Financial Economics, 3(4):305-360.

Jovanovic, B. (1982). Selection and evolution of the industry. Econometrica, 50(3):649-670.

Kaplan, S. N. and Schoar, A. (2005). Private equity performance: returns, persistence, and capital flows. Journal of Finance, 60(4):1791-1822.

Kaplan, S. N. and Strömberg, P. (2003). Financial contracting theory meets the real world: and empirical analysis of venture capital contracts. Review of Economic Studies, 70:281-315.

Kaplan, S. N. and Strömberg, P. (2004). Characteristics, contracts, and actions: evidence from venture capitalist analyses. Journal of Finance, 59(5):2177-2210.

Klepper, S. (1997). Industry life cycles. Industrial and Corporate Change, 6(1):145-181. 
Klepper, S. and Graddy, E. (1990). The evolution of new industries and the determinants of market structure. RAND Journal of Economics, 21(1):27-44.

Klepper, S. and Simons, K. L. (2005). Industry shakeouts and technological change. Journal of Industrial Organization, 23:23-43.

Knockaert, M., Lockett, A., Clarysse, B., and Wright, M. (2006). Do human capital and fund characteristics drive follow-up behaviour of early stage high-tech vcs? International Journal of Technology Management, $34(1 / 2): 7-27$.

Koenker, R. and Basset, G. (1978). Regression quantiles. Econometrica, 46(1):33-50.

Koenker, R. and Hallock, K. F. (2001). Quantile regression. Journal of Economic Perspectives, 15(4):141156.

Korteweg, A. and Sørensen, M. (2010). Risk and return characteristics of venture capital-backed entrepreneurial companies. Review of Financial Studies, 23(10):3738-3772.

Kortum, S. and Lerner, J. (2000). Assessing the contribution of venture capital to innovation. RAND Journal of Economics, 31(4):674-692.

Landajo, M., Andrès, J., and Lorca, P. (2008). Measuring firm performance by using linear and nonparametric quantile regressions. Applied Statistics, 57(2):227-250.

Lerner, J. (1999). The government as venture capitalist: the long-run impact of the SBIR program. Journal of Business, 72(3):285-318.

López-Gracia, J. and Sogorb-Mira, F. (2009). Testing trade-off and pecking order theories financing SMEs. Small Business Economics, 31:117-136.

Macmillan, I. C., Kulow, D. M., and Khoylian, R. (1989). Venture capitalists' involvement in their investments: extent and performance. Journal of Business Venturing, 4(1):27-47.

Macmillan, I. C., Siegel, R., and Subbanarasimha, P. N. (1985). Criteria used by venture capitalists to evaluate new venture proposals. Journal of Business Venturing, 1(1):119-128.

Macmillan, I. C., Zemann, L., and Subbanarasimha, P. (1987). Criteria distinguishing successful from unsuccessful ventures in the venture screening process. Journal of Business Venturing, 2(2):123-137.

Manigart, S., Baeyens, K., and Hyfte, W. V. (2002). The survival of venture capital backed companies. Venture Capital, 4(2):103-124.

Megginson, W. L. and Weiss, K. A. (1991). Venture capitalist certification in initial public offerings. Journal of Finance, 46(3):879-903.

Myers, S. and Majluf, N. (1984). Corporate financing and investment decisions when firms have information that investors do not have. Journal of Financial Economics, 13:187-221.

Ooghe, H., Laere, E. V., and Langhe, T. D. (2006). Are acquisitions worthwile? An empirical study of the post-acquisions performance of privately held belgian companies. Small Business Economics, 27:223-243.

Ooghe, H. and Wymeersch, C. V. (2006). Traité d'analyse financière. Intersentia, Antwerp. 
Sahlman, W. A. (1990). The structure and governance of venture-capital organizations. Journal of Financial Economics, 27(2):473-521.

Sapienza, H. J. (1992). When do venture capitalists add value? Journal of Business Venturing, 7(1):9-27.

Sapienza, H. J., Amason, A. C., and Manigart, S. (1994). The level and nature of venture capitalist involvement in their portfolio companies. Managerial Finance, 20(1):3-17.

Sapienza, H. J., Manigart, S., and Vermeir, W. (1996). Venture capitalist governance and value added in four countries. Journal of Business Venturing, 11:439-469.

Serrasqueiro, Z., Nunes, P. M., Leitão, J., and da Rocha Armada, M. J. (2009). Are there non-linearities between SME growth and their determinants? A quantile approach. Working paper, EFMA 2009 Annual Meeting.

Sørensen, M. (2007). How smart is smart money? A two-sided matching model of venture capital. Journal of Finance, 62(6):2725-2762.

Trigeorgis, L. (1999). Real options. The MIT Press, Cambridge, Massachusetts, London, England, 4th edition.

Tyebjee, T. T. and Bruno, A. V. (1984). A model of venture capitalist investment activity. Management Science, 30(9):1051-1066.

Vanacker, T. R. and Manigart, S. (2010). Pecking order and debt capacity considerations for high-growth companies seeking financing. Small Business Economics, 35:53-69.

Wood, G. and Wright, M. (2009). Private equity: a review and synthesis. International Journal of Management Reviews, 11(4):361-380.

Wright, M. and Robbie, K. (1998). Venture capital and private equity: a review and synthesis. Journal of Business Finance and Accounting, 25(5/6):521-570. 
Table 1: Summary of the variables

\begin{tabular}{|c|c|c|}
\hline Variable & Description & Definition \\
\hline$C F_{-} E(1)$ & Return measure, dependent variable & $\begin{array}{l}\text { Free cash flow (after taxes) / Book } \\
\text { value of equity }\end{array}$ \\
\hline$E_{-} T A(2)$ & $\begin{array}{l}\text { Company maturity measure, indepen- } \\
\text { dent variable }\end{array}$ & $\begin{array}{l}\text { Book value of equity / Book value of } \\
\text { total assets }\end{array}$ \\
\hline LOGIND (3) & $\begin{array}{l}\text { Industry maturity measure, indepen- } \\
\text { dent variable }\end{array}$ & Natural log of industrial assets' value \\
\hline$V A \_T A$ (4) & $\begin{array}{l}\text { Product maturity measure, indepen- } \\
\text { dent variable }\end{array}$ & $\begin{array}{l}\text { Value added / Book value of total as- } \\
\text { sets }\end{array}$ \\
\hline PAYOUT (5) & Payout over retention, control variable & $\begin{array}{l}\text { Dividends distributed / Retained earn- } \\
\text { ings }\end{array}$ \\
\hline$L I Q(6)$ & $\begin{array}{l}\text { Debt servicing ratio, here liquidity ra- } \\
\text { tio, control variable }\end{array}$ & $\begin{array}{l}\text { Debt charges (interest payments) } \\
\text { EBIT }\end{array}$ \\
\hline$L O G(A G E)$ & $\begin{array}{l}\text { Age of the portfolio company, control } \\
\text { variable }\end{array}$ & $\begin{array}{l}\text { Natural log of the age of the portfolio } \\
\text { firm }\end{array}$ \\
\hline$L O G(E M P L)$ & Number of employees, control variable & $\begin{array}{l}\text { Natural log of the number of number } \\
\text { of employees in full time equivalent }\end{array}$ \\
\hline INJYEARDUM (9) & $\begin{array}{l}\text { Dummy for injection year, control vari- } \\
\text { able }\end{array}$ & $\begin{array}{l}1 \text { since injection year onwards, } 0 \text { oth- } \\
\text { erwise }\end{array}$ \\
\hline$A C I D(10)$ & $\begin{array}{l}\text { Strict liquidity ratio, here acid test, } \\
\text { control variable }\end{array}$ & $\begin{array}{l}\text { (Accounts receivable }+ \text { treasury place- } \\
\text { ments }+ \text { cash }) / \text { Short term debt }\end{array}$ \\
\hline CURRENT_RATIO (11) & Current ratio, control variable & $\begin{array}{l}\text { (Current assets - long term current li- } \\
\text { abilities) / Short term debt }\end{array}$ \\
\hline$F C F \_T F(12)$ & $\begin{array}{l}\text { Free cash flow over tier funds, control } \\
\text { variable }\end{array}$ & $\begin{array}{l}\text { Free cash flow after tax / (Deferred } \\
\text { taxes and provisions }+ \text { Total Debt) }\end{array}$ \\
\hline$N E T_{-} R E N T \_C A(13)$ & $\begin{array}{l}\text { Current assets operating profitability, } \\
\text { control variable }\end{array}$ & Operating income / Current assets \\
\hline TRESO_RATIO (14) & Treasury ratio, control variable & $\begin{array}{l}\text { (Treasury placements }+ \text { cash - short- } \\
\text { term financial debt) / } \\
\text { (Current assets - long-term accounts } \\
\text { receivables) }\end{array}$ \\
\hline
\end{tabular}

The ratios are computed following Ooghe and Wymeersch (2006) discussion. 


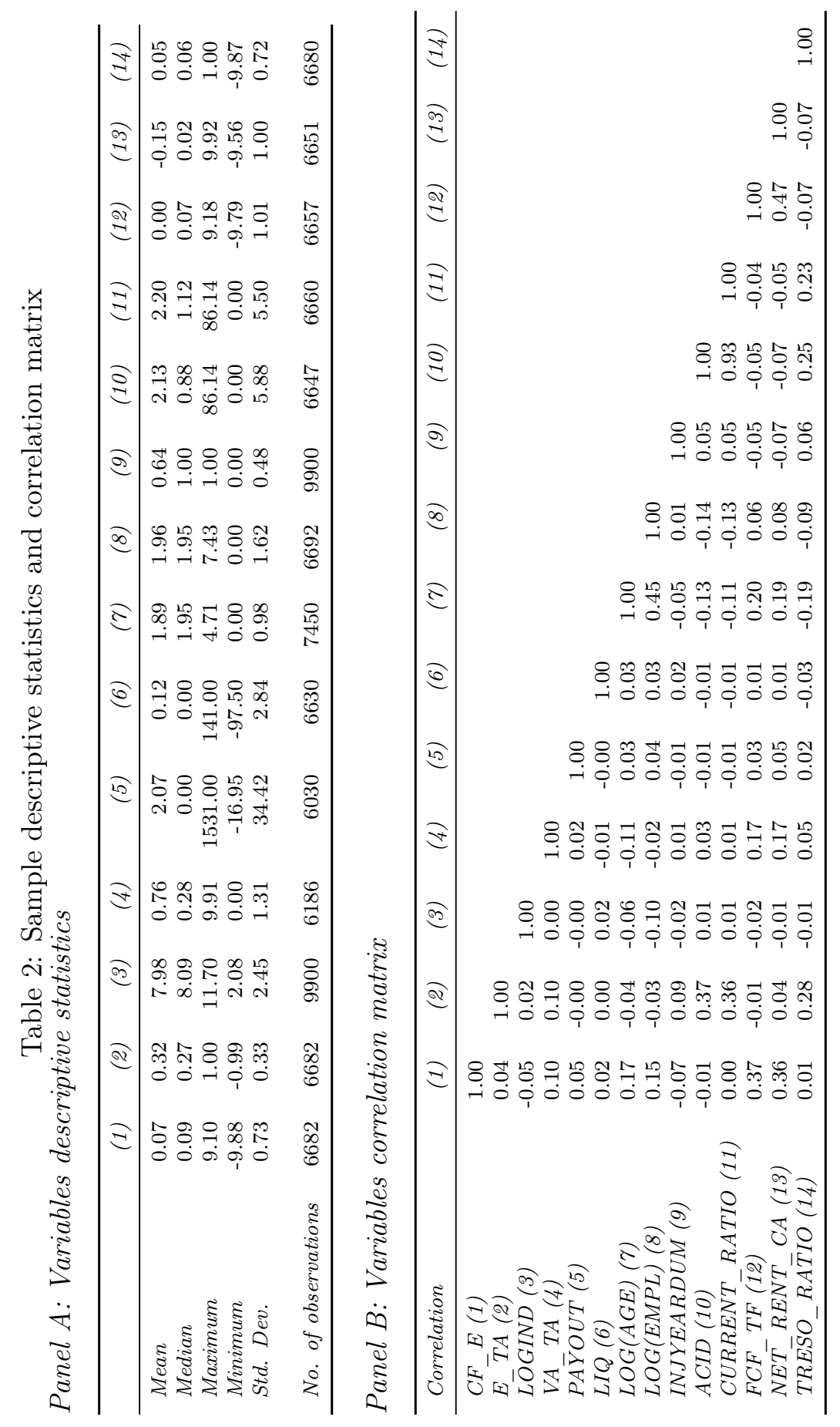




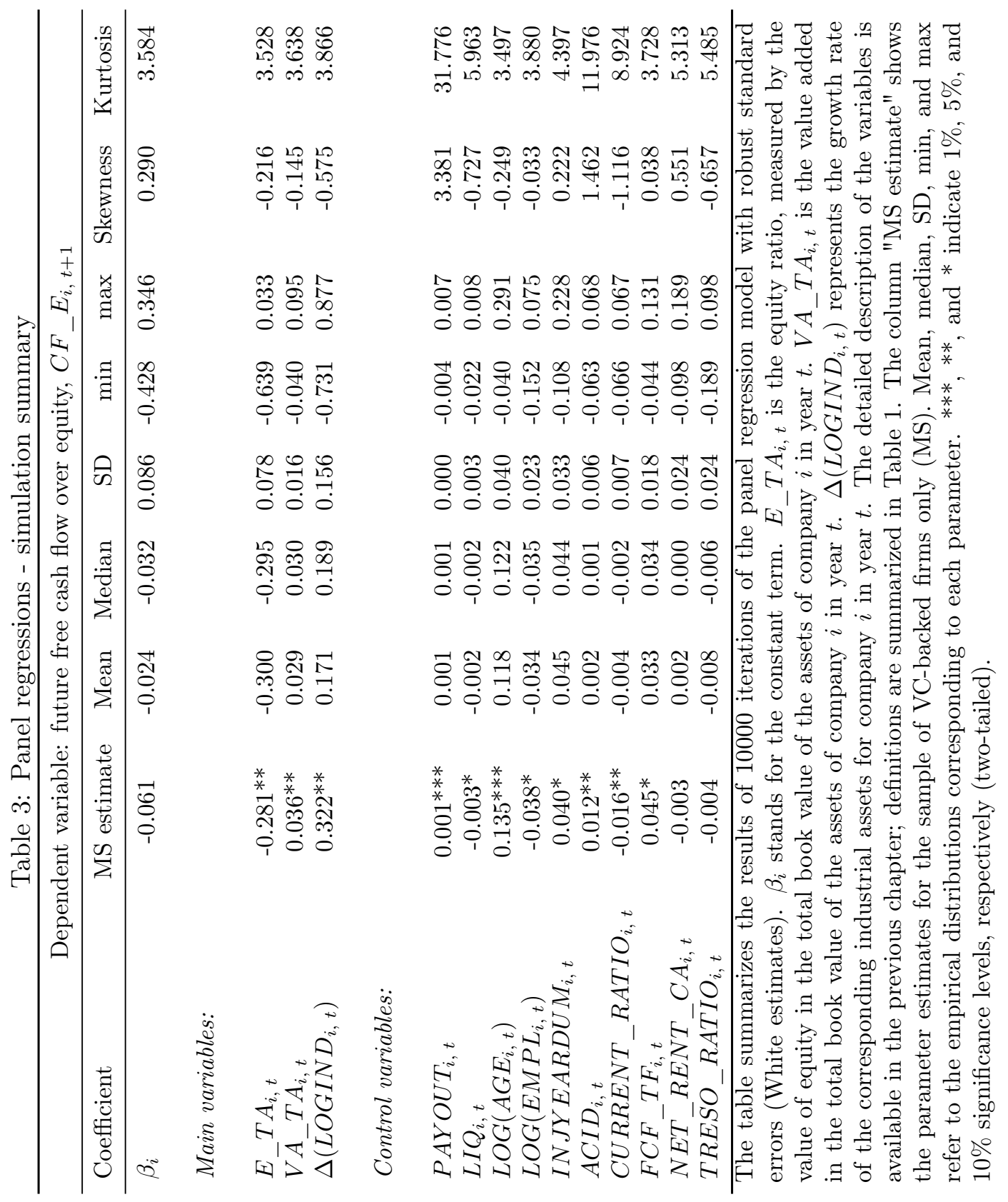


Table 4: Panel regressions - formal tests

\begin{tabular}{|c|c|c|c|c|c|c|}
\hline Variable & $\begin{array}{c}\text { MS estimate, } \\
\left(\hat{\beta}_{k}\right)\end{array}$ & Mean & $\Delta \%$ & $\begin{array}{l}H_{0}: \hat{\beta}_{k} \\
t-t e s t\end{array}$ & $\begin{array}{l}\text { Mean }=0 \\
\text { MW-test }\end{array}$ & $\operatorname{Pr}\left(\beta_{k}<\hat{\beta}_{k}\right)$ \\
\hline$E \_T A_{i, t}$ & $-0.281^{* *}$ & -0.300 & 6.33 & $* * *$ & $* * *$ & 0.586 \\
\hline$V \bar{A} \_T A_{i, t}$ & $0.036^{* *}$ & 0.029 & 24.14 & $* * *$ & $* * *$ & 0.670 \\
\hline$\Delta\left(\overline{\left.L O G I N D_{i, t}\right)}\right.$ & $0.322 * *$ & 0.171 & 88.33 & $* * *$ & $* * *$ & 0.852 \\
\hline
\end{tabular}




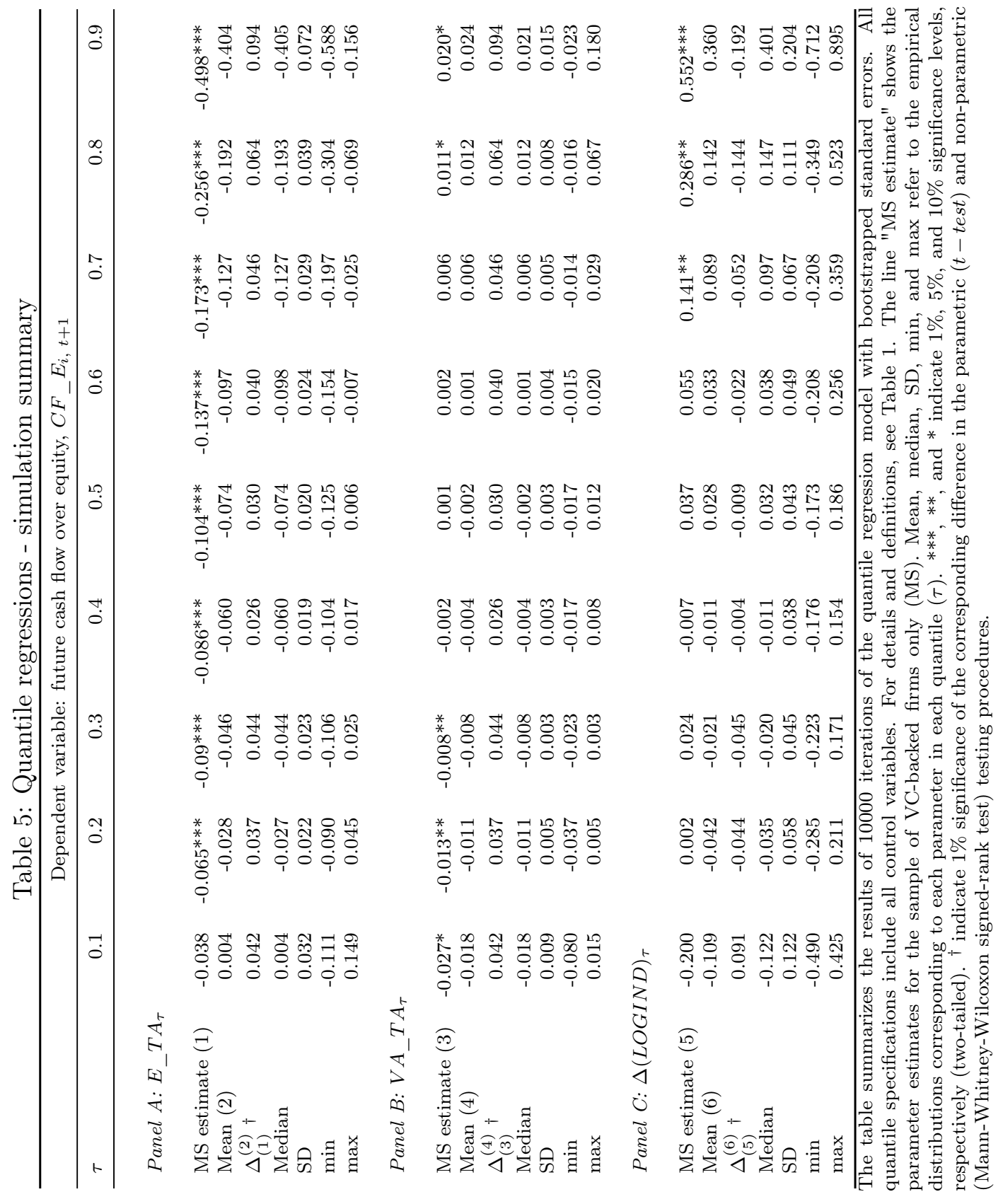


Figure 1: Panel regression approach - simulated distributions of the loadings of return determinants
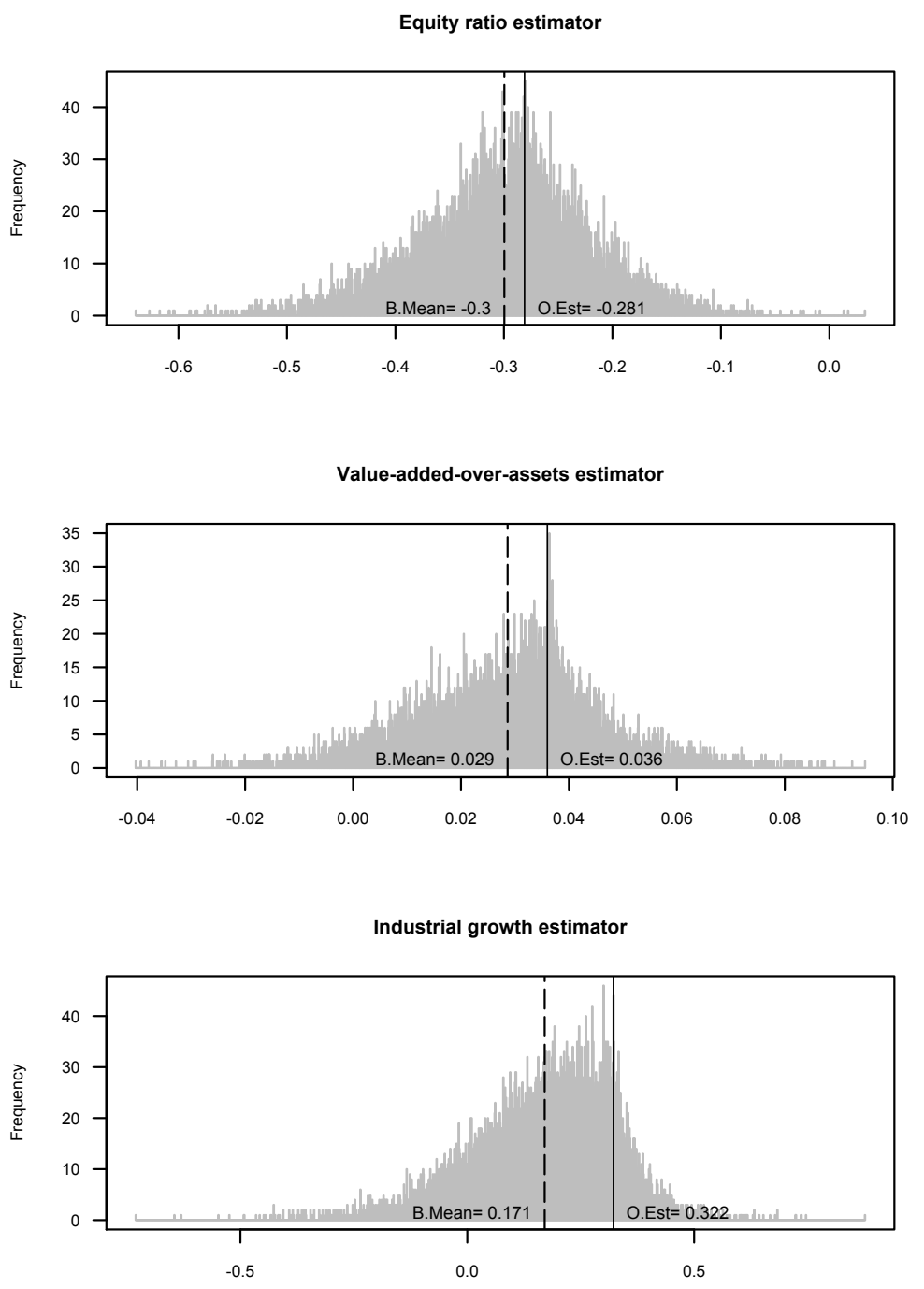

Note: The figure reports the simulated distributions of the estimators of the loadings of return determinants. Dashed lines correspond to the simulated means of the distributions. Solid lines mark the MS original estimates for the VC-backed sample only. 
Figure 2: Quantile regression approach - simulated distributions of the loadings of the Equity ratio $\left(E \_T A\right)$
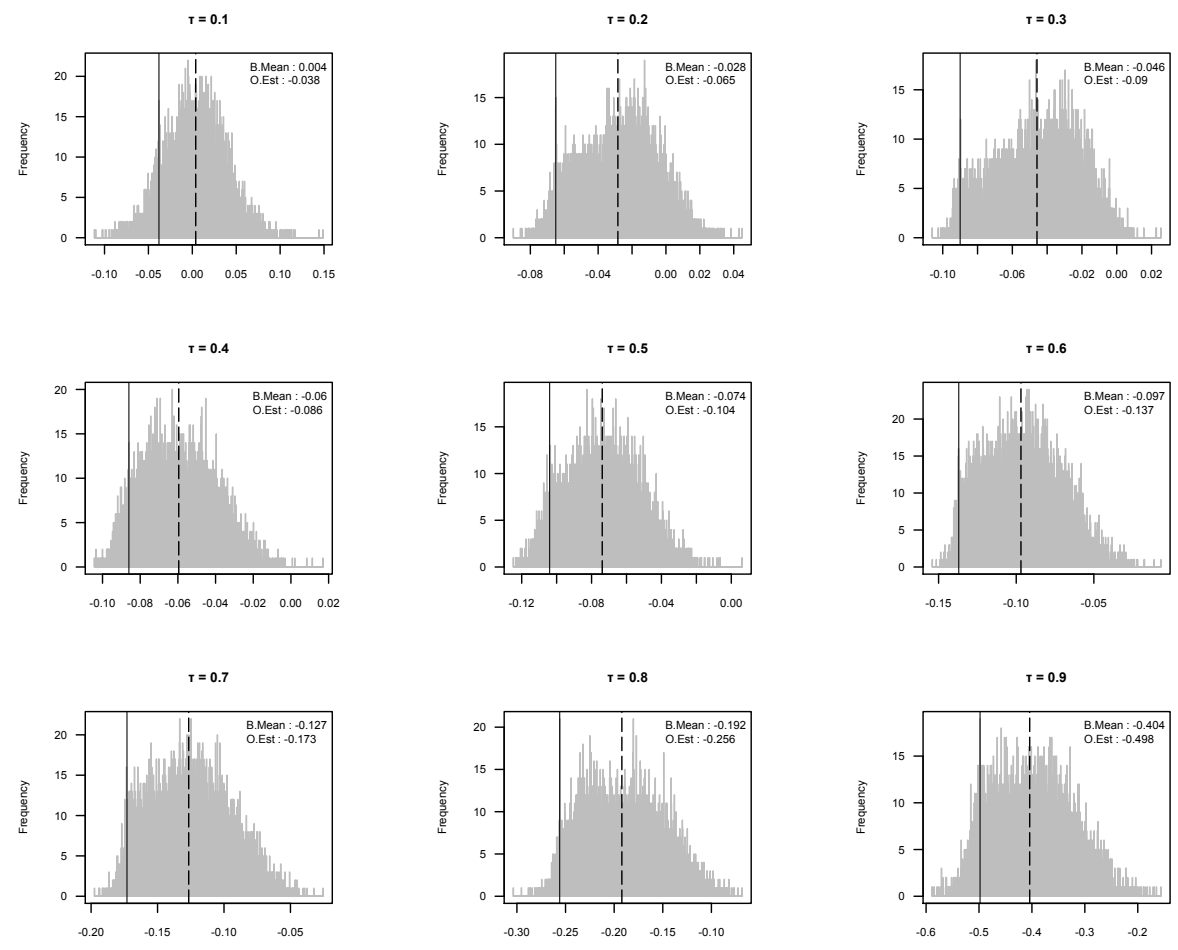

Note: The figure reports the simulated distributions of the estimators of the Equity Ratio $(E T A)$ in the quantile regression setting. Dashed lines correspond to the simulated means of the distributions. Solid lines mark the MS estimates of for the VC-backed sample only. 
Figure 3: Quantile regression approach - simulated distributions of the loadings of the Value-added-over-assets ratio $\left(V A \_T A\right)$
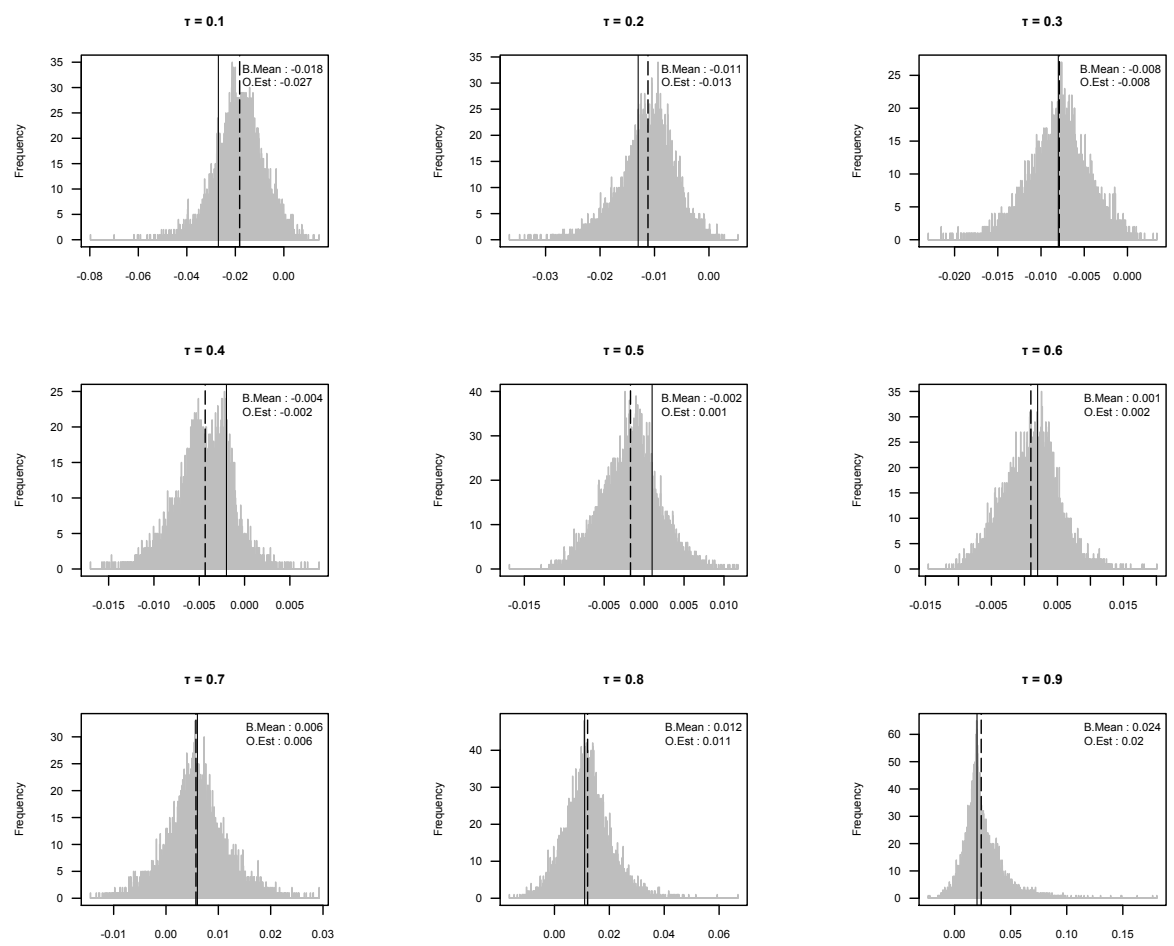

Note: The figure reports the simulated distributions of the estimators of the Value-added-over-assets ratio $\left(V A_{-} T A\right)$ in the quantile regression setting. Dashed lines correspond to the simulated means of the distributions. Solid lines mark the MS estimates of for the VC-backed sample only. 
Figure 4: Quantile regression approach - simulated distributions of the loadings of the Industrial growth rate $(\Delta(L O G I N D))$
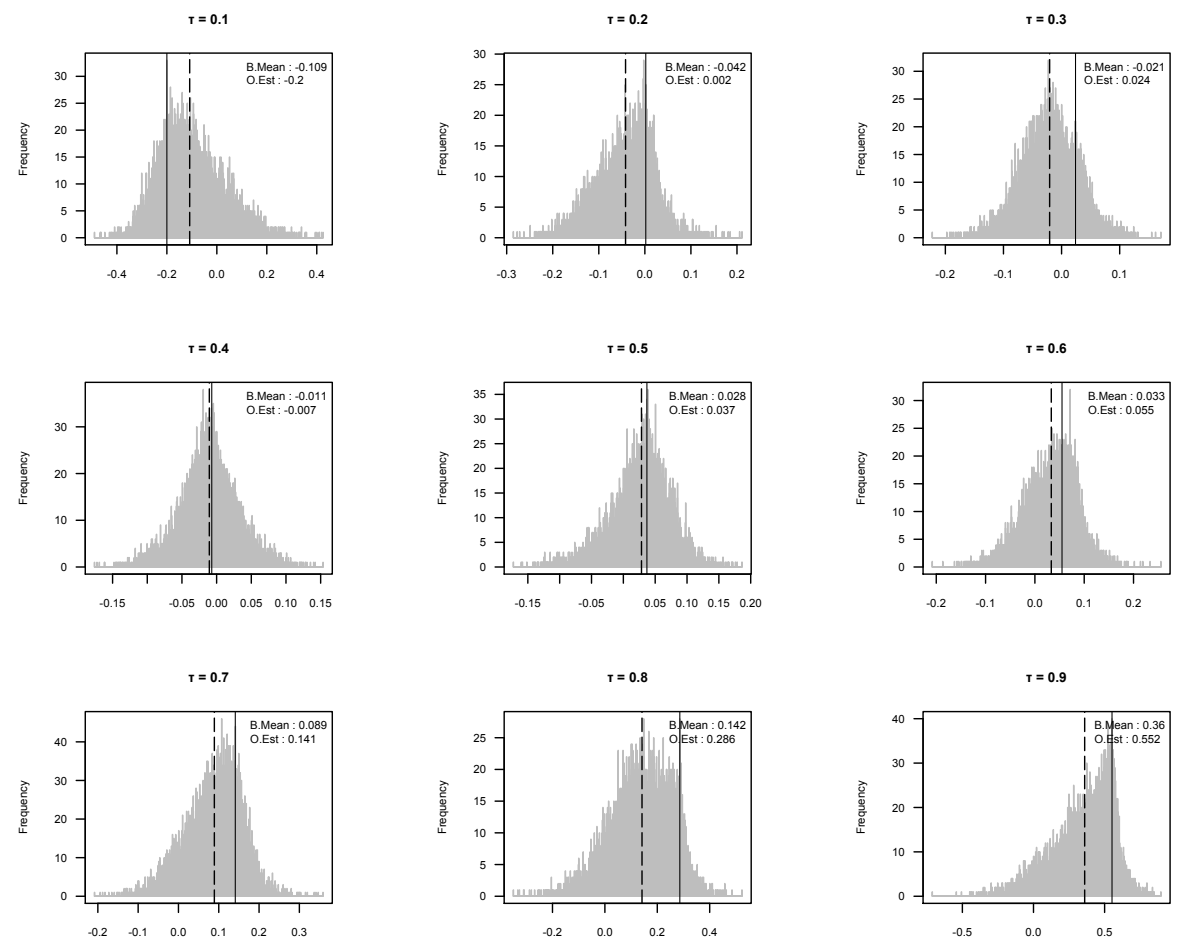

Note: The figure reports the simulated distributions of the estimators of the Industrial growth rate $(\Delta(L O G I N D))$ in the quantile regression setting. Dashed lines correspond to the simulated means of the distributions. Solid lines mark the MS estimates of for the VC-backed sample only. 